\title{
Morphological Features of Rodoretto Valley Deep-Seated Gravitational Slope Deformations
}

\author{
${ }^{1}$ Maria Gabriella Forno, ${ }^{2}$ Andrea Lingua, ${ }^{2}$ Stefano Lo Russo and ${ }^{2}$ Glenda Taddia \\ ${ }^{1}$ Department of Earth Sciences, University of Turin, Torino, Italy \\ ${ }^{2}$ Department of Environment, Land and Infrastructure Engineering, Politecnico di Torino, Torino, Italy
}

Received 2012-09-08, Revised 2012-12-11; Accepted 2012-12-11

\begin{abstract}
A new, detailed survey of the Rodoretto Valley (Western Alps, Italy) has been conducted resulting in the production of a new morphological and quaternary geological map of the area. The authors used the innovative Solid (True) Ortho-Photo (STOP) technology integrated with navigation sensors (Global Navigation Satellite System-GNSS/Inertial Measurement Unit-IMU). This state-of-the-art procedure has demonstrated several operational advantages during both the land survey and the post-processing phases. The survey highlighted remarkable glacial evidences and landforms probably connected with Deep-Seated Gravitational Slope Deformations (DSGSDs) phenomena. The glacial forms which have been detected consist of diffuse relics of cirques, glacial slopes, small lateral and frontal moraines and some outwash incisions. The deposits associated with the relics are lodgment till, flowtill and outwash sediments, respectively. The gravitational evidences and the very fractured bedrock that has been recognized on both sides of the Rodoretto Valley, suggest the presence of two DSGSDs which are confirmed also by the occurrence of some doubled ridges in the higher elevation band of the slopes. Moreover, several minor scarps and many longitudinal and transversal trenches, of various size, occur in the intermediate band. Extended landslide bodies have been recognized in the lower altimetric band. The major new geological element detected and interpreted after the survey and the map production is represented by the identification of a well defined WNW-ESE trend of fractured rocks and gravitational landforms. The observed fractures are not limited to the Rodoretto Valley, suggesting the possible connection of the described gravitational landforms with a tectonic discontinuity with the same WNW-ESE trend. This tectonic discontinuity crosses the Cenischia-Nizza System in a zone highlighted by a portion of intensively fractured rocks.
\end{abstract}

Keywords: Geological Field Survey, Quaternary, Solid True OrthoPhoto, Deep Seated Gravitational Slope Deformations (DSGSDs), Piedmont

\section{INTRODUCTION}

The recognition of deep-seated gravitational slope deformations (DSGSDs) and the investigation of their morphological features and relationships with the Quaternary evolution of alpine valleys have increased in importance during the last years.

DSGSDs and "sackung" deformations are complex processes of gravitational movement that involve large volumes of rock, often several tens of meters thick and several kilometers long. DSGSD phenomena were identified and studied long before the term was created and have continued to be a focus of research (Agliardi et al., 2001; Dramis and Sorriso-Valvo, 1984; Dramis et al., 1995; Gulla and Sorriso-Valvo, 1985; Moro et al., 2009; Radbruch-Hall et al., 1976; Savage and Varnes, 1987; Sorriso-Valvo, 1995; Zischinsky, 1969). DSGSDs are extremely slow moving, (0.4-5.0 mm/y) (Agliardi et al., 2009; Varnes et al., 1990) and produce distinctive morphological elements on the slope. These morphological features, including doubled ridges, ridgetop depressions, scarps and counterscarps, linear Corresponding Author: Maria Gabriella Forno, Department of Earth Sciences, University of Turin, Torino, Italy 
trenches, open tension cracks and ridge-crest grabens, indicate the presence of a DSGSD, particularly when observed in combination (Agliardi et al., 2001; Hurlimann et al., 2006; Jahn, 1964; Radbruch-Hall, 1978; Zischinsky, 1969).

The present research investigated the Rodoretto Valley a tributary of the Germanasca Valley, NW AlpsItaly and produced a detailed morphological definition of the glacial and gravitational sediments and landforms.

Moreover, two DSGSDs phenomena have been recognized and described. The results of the survey and the interpretation of the collected data have been synthesized in a new morphological and Quaternary geologic map of the area. The identification and the mapping of alpine DSGSDs is also very important for geotechnical problems and, due to the important infiltration through the open cracks, also to assess the infiltration (Russo et al., 2003) and to preserve the groundwater quality of mountain springs (Galleani et al., 2011).

In this study, the authors utilized a new technique (the Solid True OrthoPhoto-STOP process, (Dequal and Lingua, 2003) that allows accurate, complete and fast field data collection in a structured database yielding very good definition of the investigated glacial and gravitational evidence. These innovative tools also helped to produce the final map and to interpret the collected data. Mapping has been conducted at a scale of 1:5000 and then simplified in schematic form.

In this perspective, the innovative technology used for the survey and the map production and the geological results described in the following represent also a contribution to the more general knowledge of the alpine DSGSDs.

\section{METERIALS AND METHODS}

\subsection{The Rodoretto Valley-Regional Geological Setting}

The Rodoretto Valley, a left tributary of the Germanasca Valley, is located in the Western Alps (NW Italy) which extend from the Sestri-Voltaggio tectonic Line (SVL) (South) to the Penninic thrust Front (PF) (North) (Fig. 1). The Western Alps consist of both continental and oceanic tectonic units (Piaz et al., 1972; 1983). The continental units are the Austroalpine Domain, comprising the Sesia-Lanzo and Dent Blanche Nappe (SZ,DB) and the "Internal Crystalline Massifs" of Monte Rosa (MR), Gran Paradiso (GP) and Dora Maira (DM). These units overthrust the Elvetic Domain (1) through the Grand Saint Bernard Nappe (SB) (Fig. 1).

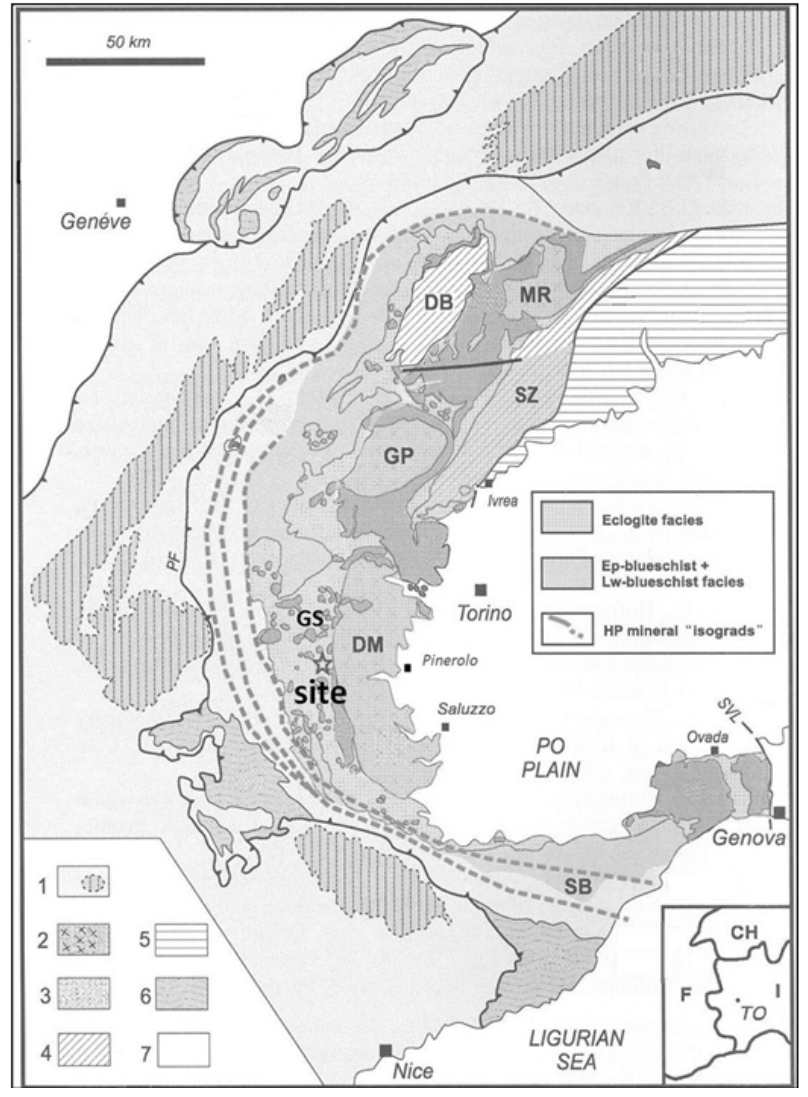

Fig. 1. Western Alps sketch map. 1: Jura, Helvetic Domain and external Penninic Domain; SB: Gran St. Bernard Zone; 2: Internal Crystalline Massif of the Penninic Domain; MR: Monte Rosa; GP: Gran Paradiso; DM: Dora Maira Massif; 3: Piedmont Zone; GS: Greenstone and Schist Complex; 4: Austroalpine Domain; DB: Dent Blanche Nappe; SZ: Sesia-Lanzo Zone; SVL: Sestri-Voltaggio Tectonic Line; PF: Penninic Thrust Front; 5: Southalpine Domain; 6: Helminthoid Flysch Nappes; 7: Swiss Molasse. Modified from Compagnoni (2003)

The oceanic units, part of the the Mesozoic Tethys, include the Piedmont Zone, in the present paper named Greenstone and Shist Complex (GS), which consists of several thrust sheets with different high-pressure metamorphic overprints. The SW extension of the Insubric Line, located between the Austroalpine Domain and the Piedmont Zone, marks the contact of the pre-Alpine Southern Alps Domain (Ivrea Zone and Strona Ceneri Zone) with the Western Alpine Chain (Compagnoni, 1977; 2003). 


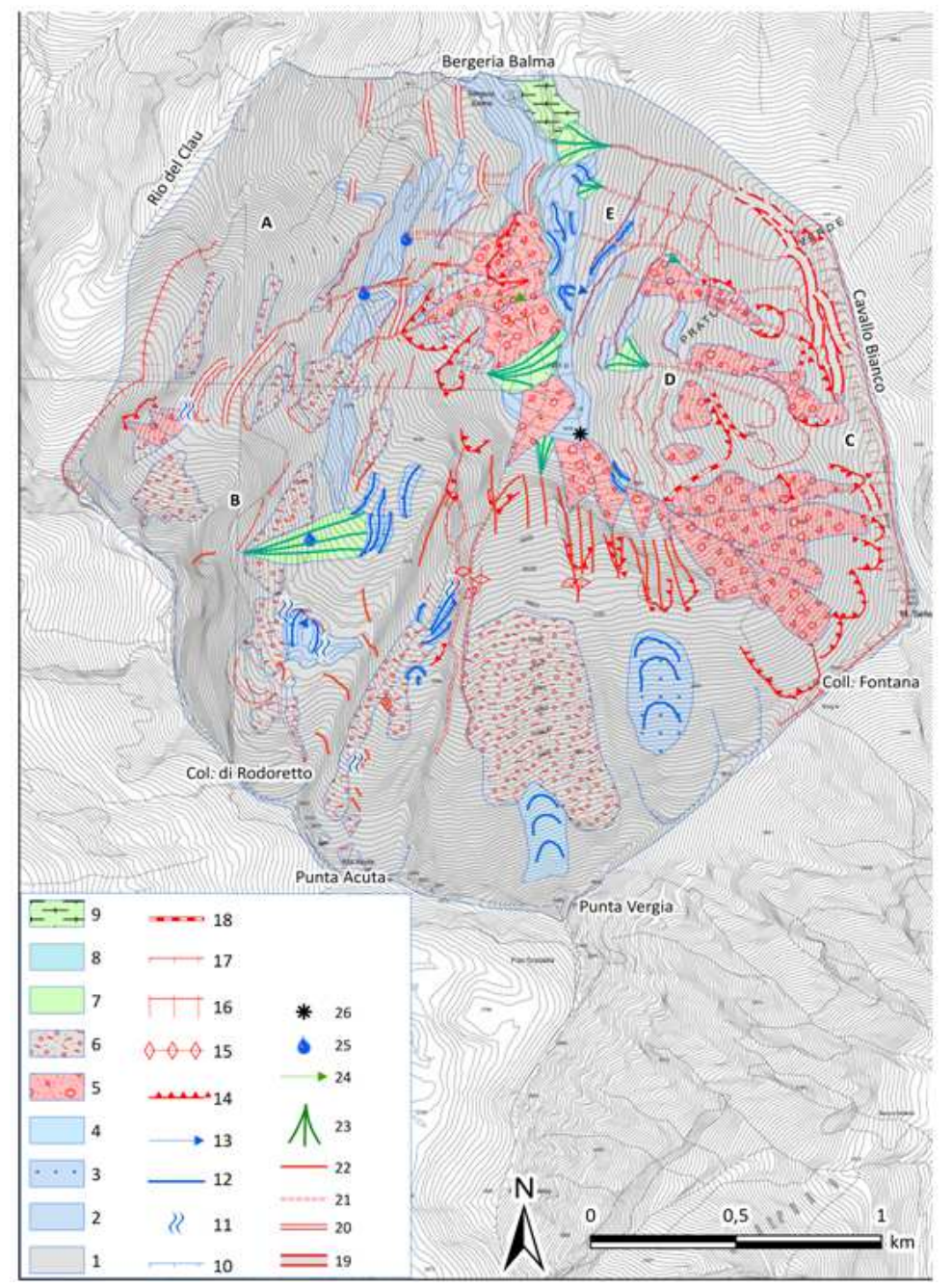

Fig. 2. Morphological and Quaternary geological map of the Rodoretto Valley, affected by glacial and gravitational lanforms. 1: bedrock (Greenstone and Schist Complex); 2: subglacial sediments; 3: glacial till; 4: rock glaciers; 5: landslide bodies; 6: debris sediments; 7: debris flow and avalanche sediments; 8: torrential sediments; 9: lacustrine sediments; 10: glacial cirques; 11: roche moutonnée; 12: moraine ridges; 13: glacial spillway channels; 14: detachment niches; 15: erosional niches; 16: main scarps; 17: minor scarps; 18: counterscarps; 19: doubled ridges; 20: transversal trenches; 21: longitudinal trenches; 22: fractures; 23: alluvial and avalanche fans; 24: paleochannels; 25: groundwater springs; 26: geographical reference point

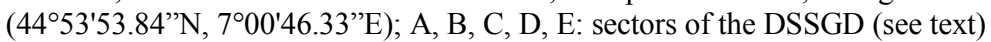

The Rodoretto Valley is located in the Penninic Domain near the N-S tectonic thrust between the Greenstone and Schist Complex (GS), in wich the area of investigation is totally shaped and the Dora Maira Massif (DM), which outcrops on the main Germanasca Valley (Sandrone et al., 1993). The Greenstone and Schist Complex (GS) consists of calcschists, quartz schist, prasinites and serpentinites (Borghi et al., 1984). The Dora Maira Massif (DM) is formed by garnet-mica schists, with chlorite and blue-green amphiboles. A recent crustal cross section from the Pelvoux Massif to the Dora Maira Massif along the south-western Alps indicates some NW-SE, about N-S and NE-SW regional structures, East of the examined area (Lardeaux et al., 2006).

The Rodoretto area is crossed by the Cenischia-Nizza System, an important N-S system of fractures in the Western Alps (Carraro et al., 1978; Forno and Massazza, 1987; Forno, 1989). In the area of investigation only 
monotonous calcshists of the Greenstone and Schist Complex (GS) occur, with a regional foliation dipping 20-30 to N30E.

The Quaternary succession of the Germanasca Valley was described only by very ancient researches and after the work of Sacco (1928) no further investigation has been performed and published. The Rodoretto Valley was first described by Novarese (1894). He divided the sediments into the "old Quaternary", consisting of ancient glacial and alluvial deposits and the "recent Quaternary", consisting of recent debris and alluvial sediments. In detail, the ancient glacial succession outcrops in the upper Germanasca Valley and in the Rodoretto Valley, where small moraines occur. This author suggested that these sediments were not formed by a single glacial phase (that occupied the entire high Germanasca Valley) as was previously thought.

The results of the geological survey conducted by Novarese in the Germanasca Valley are included in Sheet 67 "Pinerolo" geological map of Italy at a scale of 1:100.000 (Mattirolo et al., 1913), in which Wurmian and Post-Wurmian moraines, recent debris and alluvial sediments are identified in the upper Germanasca Valley.

Sacco (1928) reported a terraced glacial accumulation in the Rodoretto Valley linked to a primary rocky area (gneiss). He indicated that the glacier stopped for a long time in the Rodoretto Valley, probably in the 2rd glacial period. The Balma Village area (over $1700 \mathrm{~m}$ a.s.1.) (Fig. 2) is cut by a series of approximately twelve moraines grouped in three main complexes, referred as $1 \mathrm{rd}, 2 \mathrm{rd}$ and 3rd glacial phase of Post-Wurm glaciation, respectively. The moraines are reliefs semicircular and include huge $(5-6 \mathrm{~m})$ angular boulders. These moraines sometimes show continuity with valley deposits sourced by the surrounding snowy mountains. This author also reported irregularly curved moraines at high elevation $(2400-2500 \mathrm{~m})$, especially in the high Punta Vergia cirque (Fig. 2). He suggested that they were deposited in the first half of 19th century. Using the boulder of "Eufotide" found on the rocky ridge above $1670 \mathrm{~m}$, he suggested that the confluence of the main Germanasca and Rodoretto glaciers, both over $300 \mathrm{~m}$ thick, was probably located there. This hypothesis is consistent with the glacial shaping of the valley, its hierarchical importance, its exposure to the North and the presence of high mountains (more than $3000 \mathrm{~m}$ a.s.1.).

\subsection{A new Technique for the Data Collection and Representation}

The Quaternary sequence has been distinguished on the basis of allostratigraphic and morphologic criteria
(NACSN, 1983). In detail, the various units have been identified by the altimetric distribution, the facies and the morphological features (glacial slope, moraine ridge, alluvial fan, landslide body).

Some difficulties have been encountered related to outcrop patterns and source provenance. The wide distribution of debris and colluvial deposits mainly connected to the fracturing of rocks, diffusely covering the bedrock and the other Quaternary sediments, represent an important limitation during the field survey. The lack of petrographic variation in the area (all calcschists) does not facilitate a differentiation of sediments according to the local provenance. However to mitigate these difficulties the geomatics digital technologies facilitated the data collection during the field survey and avoid practical problems related to the transposition of these data onto topographic maps to produce the final geological map.

Digital Geological Mapping (DGM) is the process of collecting and mapping geological data using some form of portable computer and Global Navigation Satellite System (GNSS), rather than a traditional approach based on notebook and paper map (McCaffrey et al., 2005).

Digital mapping is a valuable tool. Over the past years numerous papers have discussed the methodology, software development, applications and the merits of DGM (Jones et al., 2004; Wilson et al., 2005; Clegg et al., 2006). These papers document the ongoing technological development, which has allowed unwieldy computer equipment to be replaced by lightweight and user-friendly DGM systems. Most modern users favor a DGM setup based around either a palm sized Personal Digital Assistant (PDA) or a larger Tablet PC.

The present DGM systems expose some limits due to the lack of 3D visualization and 3D data collection. In fact, the basic data of commercial DGM is a 2D map or a orthophotos that constitute the reference base for data recording and visualization. Even using GNSS and a compass, the user has difficulty correctly locating the information because he must compare what he sees (a natural $3 \mathrm{D}$ perspective view) with a $2 \mathrm{D}$ mapping base that consists of contour lines, mapping details, orthophotos and other data objects in a cartographic coordinate system. Moreover, the acquired data are located in correspondence with the position of the GNSS receiver in the 2D context and not in the their correct 3D position. To overcome these shortcomings the authors used a Solid (True) OrthoPhoto (Agliardi et al., 2001) enabled system that provides a complete 3-D land data interface and a correct aerial photographic perspective in a geo-referenced form while on-site during the survey (Forno et al., 2011). 
As shown in Fig. 3, the STOP is a new raster product of geomatics techniques that merges a digital orthophoto of analyzed land with the relative height values derived from the DDSM (Dense Digital Surface Model). Each pixel of a STOP contains the RGB color information and a height value.

An experimental software tool has been developed in Visual Fortran (with version 7.0 GINO and GINOMENU graphic libraries) to manage the STOP application. As ArcPAD/ArcScene, this user interface includes simple query functions, zoom and pan functions, a 3D coordinate viewer and the ability to take some measurements such as angles, 3D distances, areas and volumes. These features are useful during a geological field survey. A specific command prompts STOP to directly calculate (with a least squares procedure) and record dip and dip directions of planes using the 3D coordinates of their surface points; to extract the intersection between planes and the land surface and to define complex volume calculations by the intersection of the topographic surface with several planes (Fig. 4) using voxel approach. When STOP is uploaded on a commercially available tablet PC, the interface will permit the use of an electronic pen to directly map geological features in the field. STOP thus replaces the traditional topographic map. A freeware version of STOP viewer is in process, but some problems are actually due to the commercial license of GINO libraries.

The latest version of STOP viewer (Fig. 5) allows a connection with an integrated portable GNSS unit that helps to determine the surveyor's position and a low cost Inertial Measurement Unit (IMU) measures the attitude angles of the tablet PC (GNSS STOP). These navigation data are useful to generate a Solid Image
(SI) (Bornaz and Dequal, 2003) that is a natural perspective view (similar to what the user sees) integrated with a range image to define $3 \mathrm{D}$ geometry of viewed scene: the solid image allow to assist and improve the 3D geologic detail collection.

Seeing the SI directly on site, the user can record georeferenced (in a 3D mapping reference system) points, polylines and notes defined into a geo-database structure. In this research, the geoDB has been defined according to the Entity/Relation (E/R) model shown in Fig. 6.

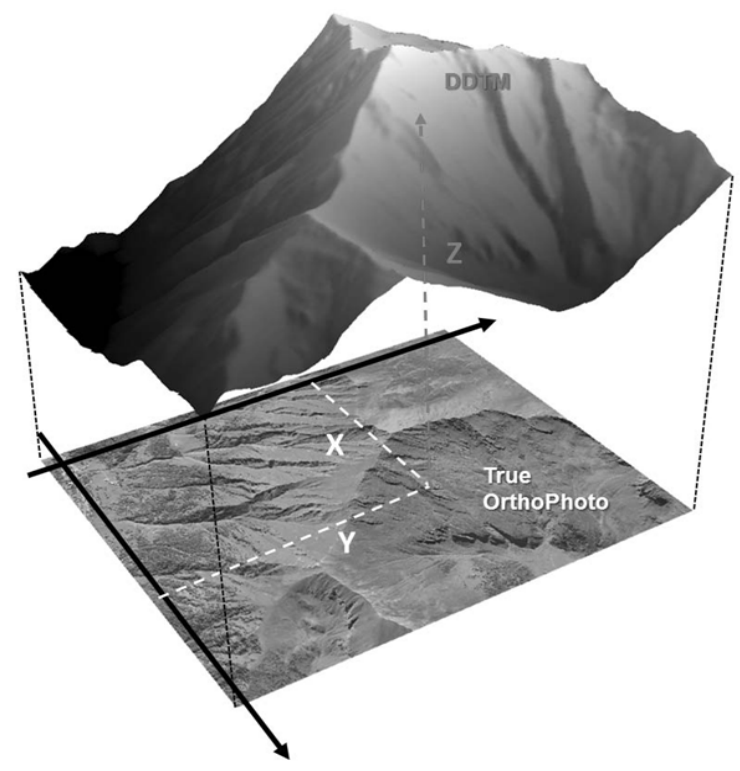

Fig. 3. Scheme of the Solid True OrthoPhotos (STOP)

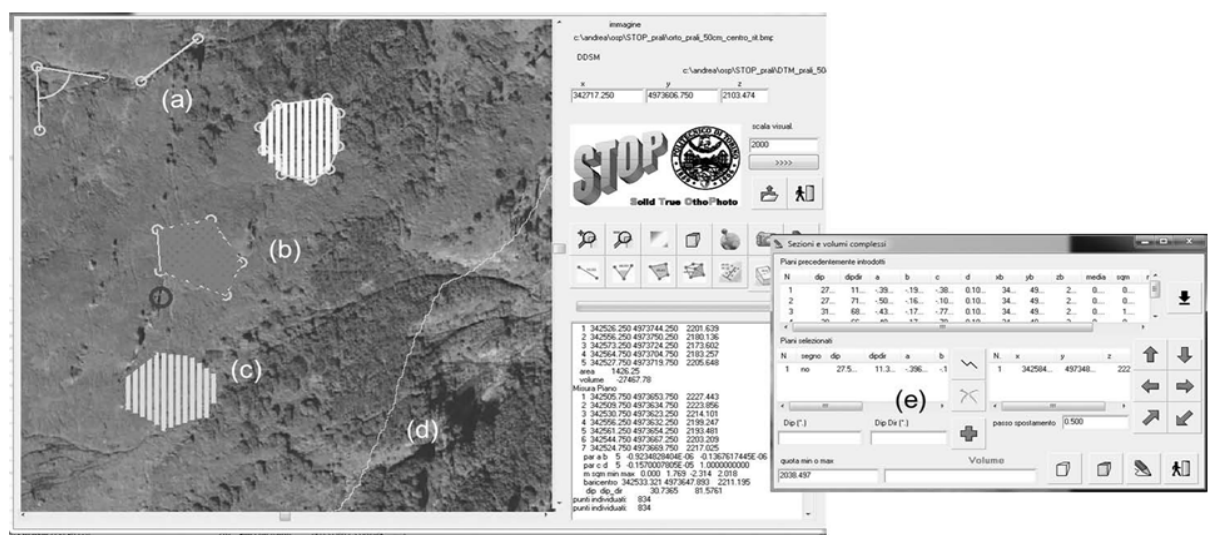

Fig. 4. The STOP viewer and its main calculation functions: (a) angles and 3D distances, (b) areas and volumes, (c) dip and dip direction of planes, (d) extraction of the intersection between planes and the land surface, (e) complex volume calculations by the intersection of the topographic surface with several planes. Scheme of the Solid True OrthoPhotos (STOP) 


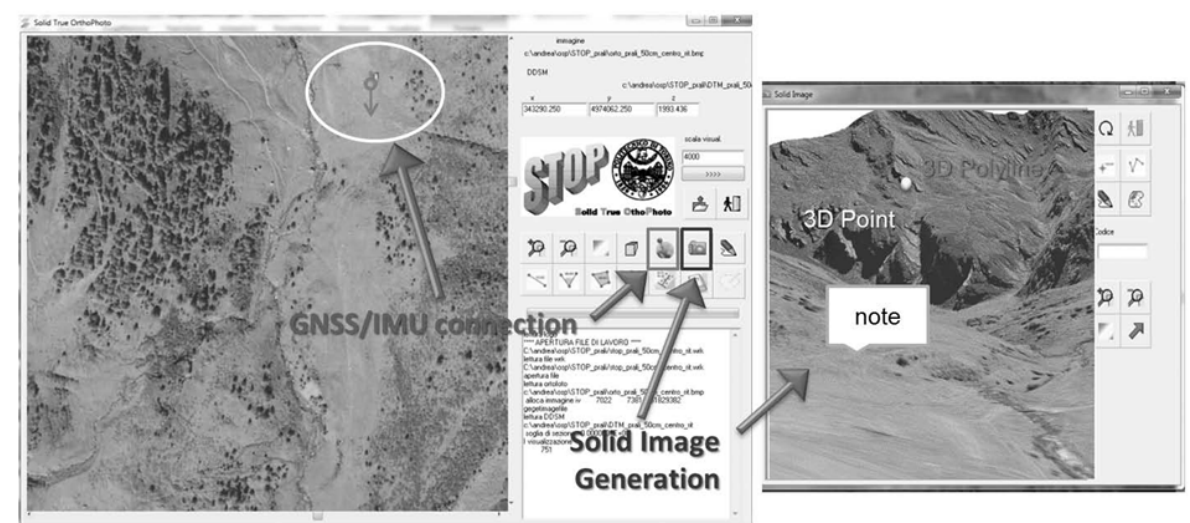

Fig. 5. The GNSS STOP viewer and Solid Image generation

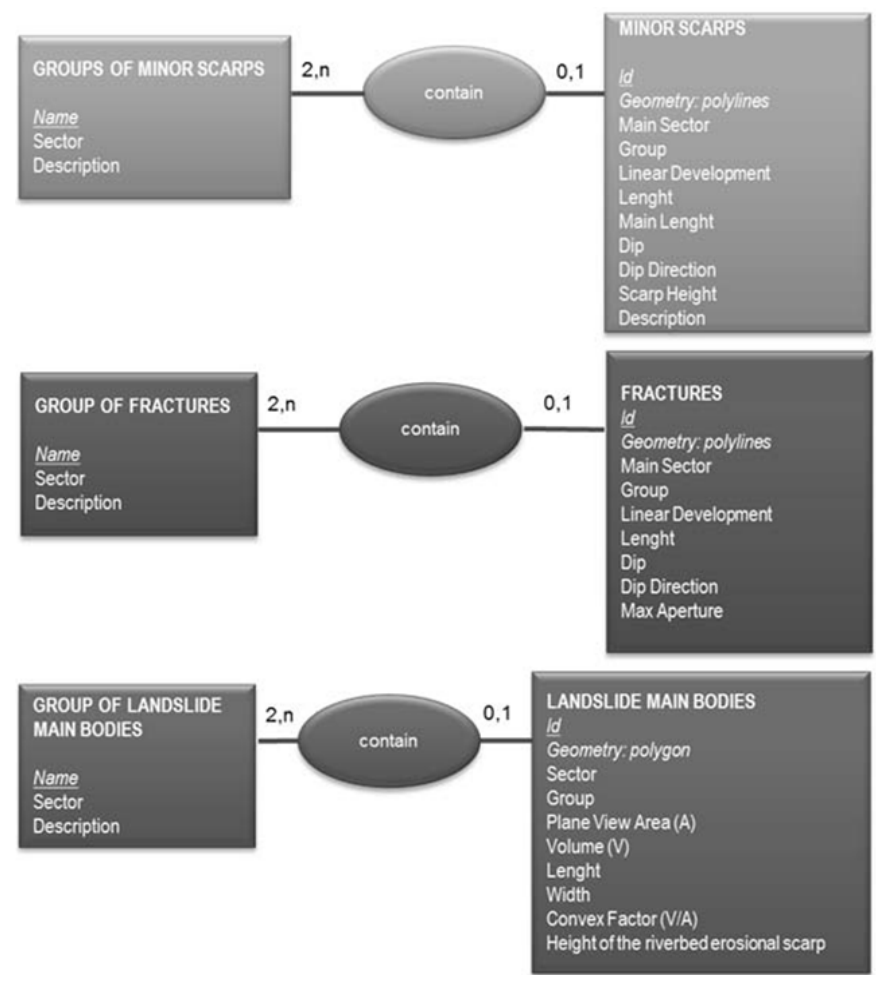

Fig. 6. The E/R model of recorded data directly used on site

\section{RESULTS AND DISCUSSION}

\subsection{The Deep-Seated Gravitational Slope Deformations}

The entire Rodoretto Valley is shaped in the monotonous calcshists of the Piedmont Zone. A lot of peculiar morphologies, as scarps, depressions and ridges elongated parallel to watersheds, has been reported. These landforms seem caused by landslides, but a larger scale. They involve, over wide areas, high fractured rocks, similar to incoherent sediments. This ensemble is the typical evidence of an area affected by DSSGD phenomena, as suggested by the extension and the high thickness of the rocky body involved. 


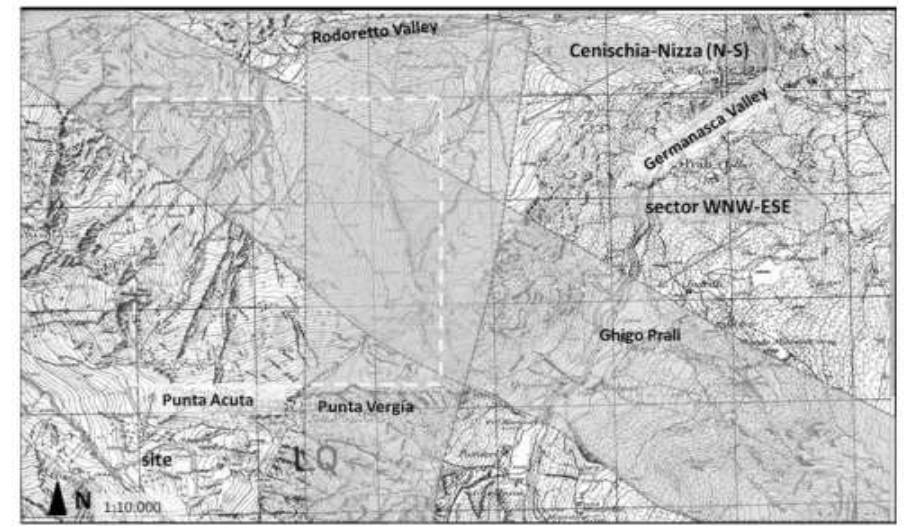

Fig. 7. The two DSGSD's mapped in Fig. 3 are comprise of a band elongated in the WNW-ESE direction and at an angle to the axis of the Rodoretto Valley. Were this band crosses the Cenischia-Nizza Fracture Zone the rocks appear disordered

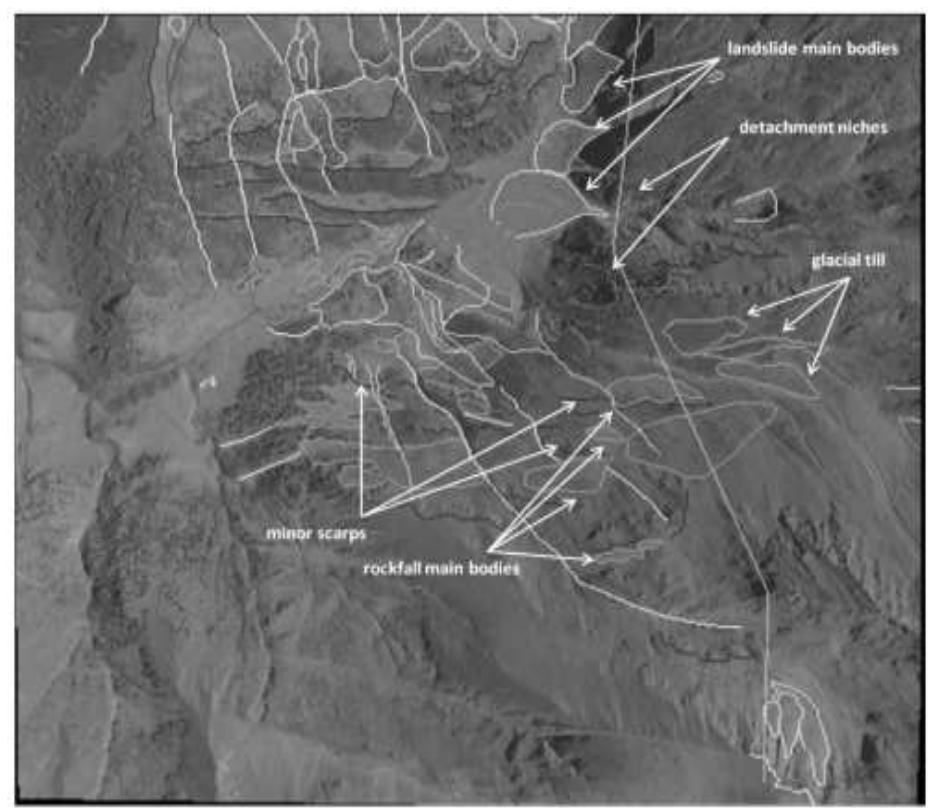

Fig. 8. The Colle di Rodoretto West side aerial photography. Numerous gravitational landforms are exhibited and reported

The area probably affected by the gravitational phenomena involve both the sides of the valley, as reported also in (Forno et al., 2011). The total area appears elongated in a WNW-ESE direction which is almost normal to the axis of the Rodoretto Valley (Fig. 7). It includes the extension developed between the Punta della Capra crest, to the West and Cavallo Bianco crest, to the East. The deformed band continues outside the investigated area with the same WNW-ESE trend (Fig. 2).

The area that exhibits the DSGSD's evidence is relatively wide at roughly $4.2 \mathrm{~km}^{2}$ (weastern side) and about $2.3 \mathrm{~km}^{2}$ (eastern side). The involved area is bounded, to the West, by the Colle di Rodoretto mountain ridge (Punta Vergia, 2990 m; Punta Acuta, 2881 m; Colle di Rodoretto, 2823 m; Punta della Capra, 2969 m; Passo della Capra, 2844 m; Monte Barifreddo, 3028 m; Passo Lungin, $2837 \mathrm{~m}$; Monte Lungin, $2921 \mathrm{~m}$; Colle della Valletta, 2690 m; Monte Pignerol, 2876 m) (Fig. 8).

This area is instead bordered, on the East, by the Cavallo Bianco mountain ridge (Colletto della Fontana, $2503 \mathrm{~m}$; Monte Selletta, $2575 \mathrm{~m}$; Cresta del Cavallo Bianco, 2493 m) (Fig. 9). 


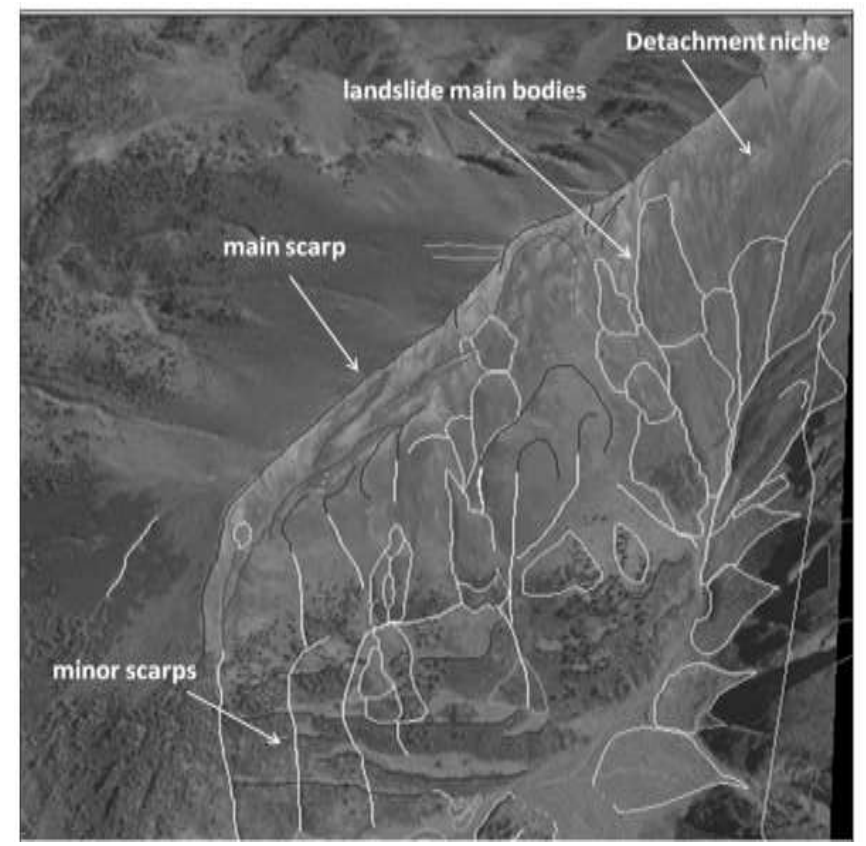

Fig. 9. The Cavallo Bianco East side aerial photography. This area provides a typical example of gravitational phenomena

The DSGSD area is limited to the SSW by a welldefined scarp that divides sectors with very fractured rocks interested by DSGSD landforms from sectors with less fractured rocks that do not exhibit a DSGSD morphology. It is also bounded to the NNE, by a sector without gravitational landforms and slightly fractured rocks. The DSGSD zone includes a lot of tributary basins (Comba Scura, Rio del Clau, Rio Rodoretto, Rio Escafe). In the area of investigation different gravitational phenomena are recognized and mapped (Fig. 2). In the two slopes they cause a different degrees of fracturing of the bedrock and several gravitational evidence of various kinds.

The western sector is, overall, slightly deformed by prevalently SSW-NNE gravitational landforms, oblique to the Rodoretto Valley (Forno et al., 2011). The relatively weak deformation is linked to the diffusion of outcropping of slightly fractured rocks and the development of many small gravitational landforms. At a local scale, the bedrock diffusely outcrops along the main crest, the secondary ridges and the numerous scarps of the slope. The slightly fractured rocks favor the development of water sources and minor surficial streams.

In the summit of this slope (2700-2990 m; A sector in Fig. 2) a noticeable SSW-NNE main scarp developed, at the head of the Rio del Clau. The main scarp cuts the large Monte Barifreddo glacial cirque, that result visibly backward by erosion. Wide alternating transversal trenches and minor scarps are clearly observed in the upper altitude range $(2500-2700 \mathrm{~m})$. The transversal trenches are connected, at the northern edge, with some roughly W-E longitudinal trenches that are very continuous and linear.

The gravitational features often dislocate some glacial esaration forms (roches moutonnées). Several transversal trenches are also present, forming locally small closed depressions or counterscarps. The numerous minor scarps are delineated by the broken plane-view profiles of the watercourses. Some water sources occur along the longitudinal trenches and give rise to small streams, demonstrating that the pattern of the hydrographic network is affected by the gravitational features. The main SSW-NNE incisions occur in longitudinal trenches, showing the same directional pattern as the smaller features.

Small detachment niches and surficial landslide accumulations are associated with the minor scarps. In the lower altitude range of the eastern side (1900-2100 m; B sector in Fig. 2), where the slope gradient is particularly high, the detachment niches and their accumulations are frequent. The niches are concave up in plan view, including several SSW-NNE stretches. The landslide accumulations continuously cover this lower band, resting on the valley floor. The different bodies show a convex cross-section and, in detail, an articulated morphology. 
The valley floor preserves the frontal sector both of the wide landslide bodies coming from the western side and of the deep-seated gravitational slope deformation interesting the eastern side. Glacial deposits and various glacial forms also occur in the valley floor representing relics of the main glacier activity.

On the contrary, the entire eastern sector is highly deformed by prevalently NNW-SSE and N-S gravitational features approximately parallel to the Rodoretto Valley. The overall pattern makes a typical deep-seated gravitational pattern resulting from diffusion of highly fractured rocks and the development of many typical morphological features.

In the upper altitude range of this slope (on the Cavallo Bianco watershed and just below the crest; C sector in Fig. 2) extended areas of intensely fractured rocks are observed. In this area the fractures favor strong erosional phenomena and secondary detachment niches. In the other sectors the substratum rarely emerges and favor erosion resulting in genesis of the material that results in the quaternary cover, suggesting a high degree of fracturing that causing the rock to be friable. The fractured rock diffusion promotes also the water flow and relatively high permeability, result in the lack of both water sources and a surficial hydrographic network.

The main gravitational features develop in the summit of the slope, just below the NNW-SSE Cavallo Bianco crest $(2300-2575 \mathrm{~m})$. Here a main scarp is continuously traceable as a very extended NNW-SSE transversal stretch and short WNW-ESE and SW-NE longitudinal stretches.

In the intermediate altitude range of the eastern slope (2300-2100 m; D sector in Fig. 2), some ensembles of minor scarps and longitudinal trenches are particularly evident because they create large depressions. The assemblages are underlain by detachment niches that are arched in plan view. The depressions are partially covered by surficial landslides. They form very complex groups of bodies, caused by a series of subsequent gravitational phenomena. The various bodies show a convex cross section and, in detail, a very articulated morphology.

A series of continuous N-S minor scarps are particularly evident in the lower altitude range of this slope (1900-2100 m; E sector in Fig. 2). They have dislocated gently sloping limbs, covered by lodgment till. These limbs, dislocated by minor scarps, are probably relics of glacial terraces. The relics appear more or less evenly spaced, thought displacement appears to get progressively greater southward. These differential movements cause a subsequent tilting toward the South of glacial limbs. Their inclination, toward the head of the valley, exhibits a counterslope trend of the glacial landforms.

The various assemblages, comprising the NNW-SSE doubled-ridges and trenches that run WNW-ESE, divide parts of the DSSGD affected by a different evolution. Only the main scarp is continuous in the entire slope.

The WNW-ESE DSGSD band interested by very fractured rocks and by numerous gravitational landforms is located in both sides of the Rodoretto Valley. It passes laterally, with a sharp boundary, to a band of weakly fractured bedrock and without significant gravitational features. This abrupt limit, located at the head of the Rodoretto Valley, is given by a WNW-ESE scarp, $150 \mathrm{~m}$ high. This scarp makes the upper Escafe Valley floor very asymmetric. The described scarp is cut by an assemblage of N-S open fractures, that are involved in winter avalanches resulting in multiple fans.

The southern area (Fig. 7) is not affected by the gravitational deformation and preserves a lot of glacial features (glacial cirques, moraine ridges, lateral moraines). This area is a calibration for the geomorphology of the area prior to extensive modification by DSGSD's. This sector is diffusely covered by coarse-grained debris sediments.

\subsection{Interpretation of the Glacial Features}

The Quaternary geological and morphological survey has also allowed to report some glacial evidence not reported in the previous geological literature (Sacco, 1928). In the upper altitude range of the Rodoretto Valley head and of the western side (about 2800-3000 m) several arched in plan scarps occur. They are very close, bounded by long N-S or SSW-NNE ridges causing secondary watershed divisions. These features are regarded as glacial cirques, exposed to $\mathrm{N}$ or NNE.

On both sides of the Rodoretto Valley numerous relics of glacial landforms and sediments occur. The main glacial evidence is several slightly inclined sectors, with diffuse fine-grained deposits covered by grass, preserved in the medium and lower altitude ranges of both sides of the valley. These areas are bounded by scarps in the bedrock and steep sectors with shrubs. Silty-gravel sediment with rounded fragments of schist are associated with these landforms. No outcrops of these sediments are recognizable, but wide areas of suboutcrop are visible (where cows graze).

The slightly inclined morphology of these areas and the presence of fine sediments with rounded elements suggest to regard them as extended strips of the glacial Rodoretto Valley slopes, covered by lodgment till. These glacial relics are discontinuously preserved at different 
altitudes in the two slopes because the described minor scarps, responsible for a marked dislocation of the glacial traces.

Also in the Rodoretto Valley floor, some slightly inclined sectors with diffuse fine-grained deposits are observed. This morphology and the associated sediments suggest to regard them as relics of the glacial valley floor, covered by lodgment till.

In the valley floor elongate ridges $(10 \mathrm{~m}$ long and some meters high) locally occur, consisting of 10 to 100 $\mathrm{cm}$ angular schist fragments mixed with a silty-sandy matrix, partially cemented by carbonate. The weakly sloped sectors are regarded as relatively wide relics of the glacial floor, covered by lodgment till. The elongate ridges are referable to lateral moraines, formed by flowtill.

At the head of the Rodoretto valley and in the western side some elongate or arched in plan ridges (8.m long and some meters high) occur at high elevation (2500-2700 m), consisting of 10 to $100 \mathrm{~cm}$ angular schist fragments. Also they are considerable lateral or frontal moraines. Wide areas with smooth rocks are preserved in the intermediate altitude range (2200-2400 m), probably connected to roches moutonnées.

In the eastern side (about 1800-2000 m) the glacial evidence is less diffuse. Only small arched in plan scarp occur in the intermediate altitude range, probably referred to glacial cirques. Below small ridges $(100 \mathrm{~m}$ long and some meters high) constitute by angular schist decimetric to metric fragments, mixed with a silty-sandy matrix and partially cemented by carbonate. The morphology and the facies of sediments promote to regard them as small moraine ridges.

\section{CONCLUSION}

\subsection{The Gravitational Evidences}

The deep-seated gravitational deformations occur in a glacial valley, shaped in the Upper Pleistocene and Holocene. Main scarps, doubled-ridges, minor scarps and trenches show various relations with the glacial cover and landforms.

The sectors of the Rodoretto Valley involved in Deep-Seated Gravitational Slope Deformation (DSGSD) occur on both sides of the valley, appearing elongated in the WNW-ESE direction at an angle to the axis of the valley. The deformed band goes beyond the Rodoretto Valley watershed and continues outside the investigated area with the same WNW-ESE trend. This elongated arrangement of the DSGSD zone also developed beyond the watersheds, suggesting a connection with a WNWESE tectonic structural discontinuity and is not yet reported in the geological literature. The NE-SW regional structures recently reported by geological and geophysical researches are probably connected to the same system (Balestro et al., 2011).

An assemblage of gravitational landforms developed on both side of the Rodoretto Valley was recognized through the geological survey using the STOP tools. The diffusion of a much fractured substratum is immediately clear. The assemblages of several gravitational landforms are also significant. The different gravitational landforms reported on the map (main scarps, doubled-ridges, minor scarps, transverse and longitudinal trenches) are fractures, included in the same DSGSD context. Their various features derive from a different stage of evolution or from a different trend or location on the slope.

At the local scale, the two sides are interested by a different gravitational deformation. The western side appears less involved. The deformation is responsible for the increasing tilt of the glacial valley relics (A and $\mathrm{B}$ sectors in Fig. 2). The eastern side is instead very dislocated. This causes a characteristic and prominent profile in plan view. The same feature causes a counterslope tilt of glacial landforms (glacial valley slope limbs and moraines) (D and E sectors in Fig. 2).

The various gravitational landforms show a different pattern. Only the main scarp and the summit doubledridges are immediately recognizable and easily correlated with gravitational features. On the contrary, other evidence as a single trench, in a different context, may be confused with a fluvial incision. Similarly, the minor scarps that dislocate the ancient slopes covered by glacial sediments, may be confused with glacial terraces divided by erosional scarps. The entire set of gravitational forms is instead clearly elucidated using the methods in this study, preventing an incorrect interpretation.

The transverse landforms (minor scarps and transverse trenches) are not as clearly demonstrated because they not interested by subsequent incision. The longitudinal landforms (longitudinal trenches) are quite clear because they are successively incised from minor streams and avalanche phenomena (on the western side) and melt snow water and avalanche phenomena (on the eastern side). The longitudinal trenches that collect surficial water and snow melt, favor the genesis of wide and relatively thick surficial landslides. Frequently, the gravitational features dislocate glacial ones (Wan et al., 2011). The more significant example is the continuous minor scarp assemblage, developed in the lower altitude range of the East slope that dislocates the original glacial slope, forming alternating sloping grassy areas and wooded 
scarps. This evidence is connected to the Holocene gravitational activity, suggesting activity continues today.

The arrangement of the DSGSD in both sides of the Rodoretto Valley, elongated in WNW-ESE direction and beyond the watersheds suggests a connection with a WNW-ESE tectonic discontinuity. The nature of this connection is not yet known and may be the subject of future study. The particularly fractured rocks recognizable in the East slope probably developed where this discontinuity crosses the Cenischia-Nizza System (Carraro et al., 1978; Forno and Massazza, 1987). The different fracture patterns of rocks of the two sides is responsible for the different maximum altitude of the West slope (Punta Vergia, 2990 m a.s.1.) and of the East slope (Colletto della Fontana, $2503 \mathrm{~m}$ a.s.1.). It is likely that the N-S trend of the valley is influenced by the Cenischia-Nizza System.

\subsection{The Glacial Evidences}

The wide extension and the lower altitude of the described landforms in the Rodoretto Valley floor and in the low altimetric band of both the slopes (E sector) indicate a connection to the main Rodoretto Glacier, probably in the late glacial in age.

The short extent and the high elevation of the evidence located in the upper altimetric band of western sector suggest small lateral glaciers, characterized by three different locations of the fronts during the Holocene.

The intermediate altitude range of the eastern side (about 1800-2000 m) exhibits only small glacial cirques. Their features indicate that they occupy the small depressions formed by the gravitational minor scarps and detachment, exposed to the west. Very small lateral and frontal moraines formed by flowtill occur, associated with these cirques.

The assemblage of described features is connected to some local glaciers, now extinct, prevalently exposed to the north. They suggest three successive retreat stages that characterized the lateral glaciers that were once tributaries of the main Rodoretto Glacier and successively from localized suspended glaciers.

All these glacial traces are dislocated by gravitational landforms. Particularly interesting is the arrangement of strips of the glacial valley slopes that are dislocated by gravitational minor scarps and inclined toward the head of the valley demonstrating local counterslope features.

The planned comparison of aerial photographs of different ages could lead a to a better definition of the recent evolution of the gravitational phenomena. Further structural geological investigations, focused on the entire WNW-ESE tectonic discontinuity, could allow for a better understanding of its development and geodynamic significance.

The new collected data are regarded as preliminary individuation and description. The area would be subjected to structural research to better comprise and comprise the quaternary evolution of the area. Particularly the WNW-ESE tectonic discontinuity require detailed structural geological investigation.

\section{ACKNOWLEDGEMENT}

The researchers thank Paolo Maschio, photogrammetry laboratory for his assistance during the analysis and vision the Ortho Photo and data processing.

\section{REFERENCES}

Agliardi, F., G. Crosta and A. Zanchi, 2001. Structural constraints on deep-seated slope deformation kinematics. Eng. Geol., 59: 83-102. DOI: 10.1016/S0013-7952(00)00066-1

Agliardi, F., G. Crosta, A. Zanchi and C. Ravazzi, 2009. Onset and timing of deep-seated gravitational slope deformations in the eastern Alps, Italy. Geomorphology, 103: 113-129. DOI: 10.1016/j.geomorph.2007.09.015

Balestro, G., G. Fioraso and B. Lombardo, 2011. Geological map of the upper Pellice Valley (Italian Western Alps). J. Maps, 2011: 634-654.

Borghi, A., P. Cadoppi, A. Porro, R. Sacchi and R Sandrone, 1984. Osservazioni geologiche nella Val Germanasca e nella media Val Chisone (Alpi Cozie). Boll. Mus. Reg. Sc. Nat. Torino, 2: 503-526.

Bornaz, L. and S. Dequal, 2003. A new concept: the solid image. Proceedings of XIXth International Symposium, (IS' 03), pp: 169-174.

Carraro, F., E. Ferrero, M.G. Forno and B. Ricci, 1978. Dati Preliminari Sull'evoluzione Neotettonica Dell'arco Delle Alpi Occidentali. In: Contributi Preliminari Alla Realizzazione Della Carta Neotettonica d'Italia, Aa, V.V. (Ed.), CNR Progetto Finalizzato Geodinamica, pp: 235-249.

Clegg, P., L. Bruciatelli, L. Domingos, R.R. Jones and D.M. Donatis et al., 2006. Digital geological mapping with tablet PC and PDA: A comparison. Comput. Geosci., 32: 1682-1698. DOI: 10.1016/j.cageo.2006.03.007

Compagnoni, R., 1977. The Sesia-Lanzo zone: High pressure-low temperature metamorphism in the Austroalpine continental margin. Rend. Soc. Ital. Miner. Petrol., 33: 335-374. 
Compagnoni, R., 2003. HP metamorphic belt of the western Alps. Episodes, 26: 200-204.

Dequal, S. and A. Lingua, 2003. True orthophoto of the whole town of Turin. Int. Arch. Photogram Remote Sens., 34: 1682-1750.

Dramis, F. and M. Sorriso-Valvo, 1984. Deep-seated gravitational slope deformations, related landslides and tectonics. Eng. Geol., 38: 231-243. DOI: 10.1016/0013-7952(94)90040-X

Dramis, F., P. Farabollini, B. Gentili and G. Pambianchi, 1995. Neotectonics and Large-Scale Gravitational Phenomena in the Umbria-Marche Apennines. 1st Edn., Wiley and Sons Ltd., Italy.

Forno, M.G. and G. Massazza, 1987. Movimenti gravitativi diffusi e ripetuti nel versante sinistro della Val Cenischia (Alpi Graie) e loro relazione con il sistema di fratture Cenischia-Nizza. Geogr. Fis. Dinam. Quatern., 10: 277-306.

Forno, M.G., 1989. Osservazioni su alcune frane oloceniche di grandi dimensioni nel settore alpino occidentale. Boll. Soc. Geol. Ital., 108: 409-418.

Forno, M.G., A. Lingua, S. Lo Russo and G. Taddia, 2011. Improving digital tools for Quaternary field survey: A case study of the Rodoretto Valley (NW Italy). Environ. Earth Sc., 64: 1487-1495. DOI: 10.1007/s12665-011-0971-6

Galleani, L., B. Vigna, C. Banzato and S.L. Russo, 2011. Validation of a vulnerability estimator for spring protection areas: The VESPA index. J. Hydrol., 396: 233-245. DOI: 10.1016/j.jhydrol.2010.11.012

Gulla, G. and M. Sorriso-Valvo, 1985. Deep-seated block slides and lateral spreads in Calabria. Proceedings of the International Symposium on Erosion, Flow and Disaster Prevention, Sept. 3-5, Tsukuba, Japan, pp: 311-316.

Hurlimann, M., A. Ledesma, J. Corominas and P.C. Prat, 2006. The deep-seated slope deformation at Encampadana, Andorra: Representation of morphologic features by numerical modelling. Eng. Geol., 83: 343-357. DOI: 10.1016/j.enggeo.2005.11.008

Jahn, A., 1964. Slope morphological features resulting from gravitation. Zeitschrift Fur Geomorphologie, 5: 59-72.

Jones, R.R., K.J.W. McCaffrey, R.W. Wilson and R.E Holdsworth, 2004. Digital Field Acquisition: Towards Increased Quantification of Uncertainty During Geological Mapping. In: Geological Prior Information: Informing Science and Engineering, Curtis, A. and R. Wood (Eds.), Geological Society, London, ISBN-10: 1862391718, pp: 43-56.
Lardeaux, J.M., S. Schwartz, P. Tricart, A. Paul and S. Guillot et al., 2006. A crustal-scale cross-section of the south-western Alps combining geophysical and geological imagery. Terra Nova., 18: 412-422. DOI: 10.1111/j.1365-3121.2006.00706.x

Mattirolo, E., V. Novarese, S. Franchi and A. Stella, 1913. Foglio geologico 67 "Pinerolo" della Carta Geologica d'Italia alla scala 1:100.000. Serv. Geol. Ital.

McCaffrey, K.J.W., R.R. Jones, R.E. Holdsworth, R.W. Wilson and P. Clegg et al., 2005. Unlocking the spatial dimension: Digital technologies and the future of geoscience fieldwork. J. Geol. Soc., 162: 927-938. DOI: 10.1144/0016-764905-017

Moro, M., M. Saroli, C. Tolomei and S. Salvi, 2009. Insights on the kinematics of deep-seated gravitational slope deformations along the 1915 Avezzano earthquake fault (Central Italy), from time-series DInSAR. Geomorphology, 112: 261276. DOI: 10.1016/j.geomorph.2009.06.011

NACSN, 1983. North American stratigraphic code. Am. Ass. Petr. Geol. Bull., 67: 841-875.

Novarese, V., 1894. Note originali sul rilevamento geologico eseguito nel 1894 in Valle della Germanasca. Boll. Del R. Com. Geol. It., 6: 254-282.

Piaz, G.V.D., B. Lombardo and G. Gosso, 1983. Metamorphic evolution of the Mt. Emilius Klippe, Dent Blanche nappe, Western Alps. Am. J. Sci., 283-A: 438-458.

Piaz, G.V.D., J.C. Hunziker and G. Martinotti, 1972. La Zona Sesia-Lanzo e l'evoluzione tettonometamorfica delle Alpi nord-occidentali interne. Mem. Soc. Geol. Ital., 11: 433-460.

Radbruch-Hall, D., 1978. Gravitational Creep of Rock Masses on Slopes. In: Rockslides and Avalanches: Natural Phenomena, Voight, B. (Ed.), Elsevier Science Ltd, Amsterdam, ISBN-10: 0444415076, pp: 608-657.

Radbruch-Hall, D., D.J. Varnes and W.Z. Savage, 1976. Gravitational spreading of steep-sided ridges ("sackung") in Western United States. Bull. Int. Assoc. Eng. Geol., 14: 23-35. DOI: 10.1007/BF02634754

Russo, S.L., L. Zavattaro, M. Acutis and G.M. Zuppi, 2003. Chloride profile technique to estimate water movement through unsatured zone in a cropped area in subhumid climate. J. Hydrol., 270: 65-74. DOI: 10.1016/S0022-1694(02)00278-0

Sacco, F., 1928. Il glacialismo delle Valli di Pinerolo. Boll. R. Uff. Geol. Ital., 53: 11-14. 
Sandrone, R., P. Cadoppi, R. Sacchi and P. Vialon, 1993. Pre-Mesozoic Geology in the Alps. In: The Dora Maira Massif, Raumer, J.F.V. and F. Neubaur (Ed.), Springer Verlag.

Savage, W.Z. and D.J. Varnes, 1987. Mechanics of gravitational spreading of steep-sided ridges («sackung»). Bull. Int. Assoc. Eng. Geol., 35: 31-36. DOI: 10.1007/BF02590474

Sorriso-Valvo, M., 1995. Considerazioni sul limite tra deformazione gravitativi profonda di versante e frana. Mem. Soc. Geol. Ital., 50: 179-185.

Varnes, D.J., D. Radbruch-Hall, K.L. Varnes, W.K. Smith and W.Z. Savage, 1990. Measurement of Ridge-spreading Movements (Sackungen) at Bald Eagle Mountain, Lake County, Colorado, 1975-1989. US Geol. Survey Open-File Report.
Wan, Y., K. Fu, Y. Liu and Z. Shi, 2011. Geomorphologic structure, characteristics and processes in the Cangshan mountains: Explanations for the formation and development of the Dali Glaciation. Int. J. Geosci., 2: 155-163.

Wilson, R.W., K.J.W. McCaffrey, R.R. Jones, P. Clegg and R.E. Holdsworth, 2005. Digital mapping of Lofoten's faults. Geoscientist, 15: 4-9.

Zischinsky, U., 1969. Uber sackungen. Rock Mech., 1: 30-52. DOI: $10.1007 / \mathrm{BF} 01247356$ 